УДК 378. 174:004

Карпенко Свгенія Миколаївна

кандидат педагогічних наук, старший викладач

Житомирський державний університет імені Івана Франка, м. Житомир, Україна

karpenko26@i.ua

\title{
МУЛЬТИМЕДІЙНІ ПРОГРАМНІ ЗАСОБИ У ПІДГОТОВЦІ МАЙБУТНЬОГО ФАХІВЦЯ 3 ІНОЗЕМНИХ МОВ У ДОШКІЛЬНІЙ ТА ПОЧАТКОВІЙ ОСВІТІ
}

\begin{abstract}
Анотація. У статті розглядаються можливі шляхи поетапного використання мультимедійних комп'ютерних програмних засобів у процесі фахової підготовки майбутнього фахівця 3 іноземних мов початкової ланки, які відповідають інноваційним освітнім тенденціям. Завданням учителя є побудувати навчальний процес, зокрема так, щоб дітям було цікаво. Автор аналізує поняття мультимедійних комп'ютерних програмних засобів i пропонує можливі шляхи поетапного формування умінь використання мультимедійних комп'ютерних програмних засобів майбутніми вчителями іноземних мов початкової ланки. Це надасть можливість майбутньому вчителю самостійно скомпонувати навчальний матеріал, щоб домогтися максимального навчального ефекту.
\end{abstract}

Ключові слова: мультимедійні комп'ютерні програмні засоби; майбутній учитель іноземних мов початкової ланки; анімація; звукові ефекти; графіка; мультимедія.

\section{1. ВСТУП}

Постановка проблеми. Сучасна модель освіти націлена на розвиток особистості через призму формування життєво необхідних компетентностей. Формування компетентної особистості - мислячої, самостійної, творчої - соціальне замовлення інформаційного суспільства. Упровадження нових освітніх технологій у процес фахової підготовки майбутнього фахівця 3 іноземних мов початкової ланки сприятиме формуванню у студентів умінь працювати 3 даними упродовж життя: здобувати іiі, переробляти, передавати, застосовувати їх 3 метою індивідуального розвитку i самовдосконалення, а також умінь використовувати сучасні комп'ютерні технології, зокрема, мультимедійні комп'ютерні програмні засоби, у власній професійній діяльності, що є невід’ємною рисою фахівця з іноземних мов початкової ланки XXI століття [1].

Аналіз останніх досліджень і публікацій. Дослідження проблеми використання комп'ютерних програмних засобів у сфері освіти, що беруть початок з другої половини XX століття, представлені: працями в галузі філософії, психології, педагогіки, насамперед, роботи М. Кларіна, Дж. Гербнера (G. Gerbner), О. Бурім, В. Беспалько, Л. Морської та інших. Психологічний аспект впливу мультимедійних комп'ютерних програмних засобів на особистість досліджували О. Бурім, Ю. Усов, К. Мелоні (Christine Meloni); застосування у педагогіці мультимедійних комп'ютерних програмних засобів розглядали у своїх дослідженнях В. Беспалько, Л. Морська, Н. Ротмістров, Г. Шетцер (Heidi Shetzer) та інші. Так, наприклад, Н. Ротмістров вважає, що мультимедійні комп'ютерні програмні засоби дозволяють підійти до перетворення комп'ютера у могутній засіб освіти, у якому змодельовані всі аспекти процесу навчання - від методичного до презентаційного [4, с. 89]. Однак, нам невідомі результати комплексного дослідження впровадження нових освітніх технологій у процес фахової підготовки майбутнього фахівця з іноземних мов в дошкільній і початковій освіті, що зумовлює актуальність нашого дослідження. 
Мета статті. Метою статті $\epsilon$ окреслення теоретичних засад використання мультимедійних комп'ютерних програмних засобів у процесі фахової підготовки майбутнього фахівця з іноземних мов початкової ланки.

\section{2. МЕТОДИ ДОСЛІДЖЕННЯ}

У нашому дослідженні ми використовуємо такі методи: теоретичні - аналіз філософської, педагогічної і психологічної літератури, що дають можливість уточнити характер основних понять дослідження, систематизації й узагальнення теоретичних $\mathrm{i}$ емпіричних даних, за допомогою яких ми маємо змогу показати реальний стан можливості використання мультимедійних комп'ютерних програмних засобів у процесі фахової підготовки майбутнього фахівця з іноземних мов початкової ланки.

\section{3. РЕЗУЛЬТАТИ ДОСЛІДЖЕННЯ}

Виклад основного матеріалу. Термін "мультимедія" (від англійського терміну multimedia - багатокомпонентне середовище) визначається як сукупність комп'ютерних технологій, у якій одночасно використовується кілька інформаційних середовищ: графіка, текст, відео, фотографія, анімація, звукові ефекти, високоякісний звуковий супровід Використання інформаційних технологій кардинально розширює можливості вчителя-філолога у виборі матеріалів і форм навчальної діяльності, робить заняття яскравими і захоплюючими. Велику ефективність мають мультимедійні комп'ютерні програмні засоби, які дозволяють користувачеві одночасно сприймати аудіо- i візуальну інформацію. Учені вважають, що комп'ютерні програмні засоби дозволяють підійти до перетворення комп'ютера у могутній засіб освіти, у якому змодельовані всі аспекти процесу навчання - від методичного до презентаційного [3].

Як і у випадку з будь-якими засобами навчання, для грамотного використання мультимедійних комп'ютерних програмних засобів у навчальному процесі необхідно знати його дидактичні властивості, щоб визначити його роль і місце в навчальному процесі у вузі. Найбільш значущими дидактичними властивостями мультимедійних комп'ютерних програмних засобів як засобу формування інформаційної компетентності у процесі фахової підготовки майбутнього вчителя іноземних мов початкової ланки є можливість обробки різної автентичної інформації (текстової, звукової, графічної, мультимедійної, зокрема за допомогою Інтернет-технологій), що сприяє формуванню вмінь здобувати дані з різних джерел з наступною їх обробкою.

Використання мультимедійних комп'ютерних програмних засобів у процесі фахової підготовки майбутнього фахівця з іноземних мов початкової ланки може бути організовано в різних аспектах: в очному навчанні на окремих заняттях, у підготовці телекомунікаційних проектів, для участі в дистанційних олімпіадах, конкурсах, для виконання індивідуальних завдань; очно-дистанційному навчанні, за якого деякі блоки, модулі, теми виносяться для дистанційного вивчення, або студент за необхідності може вивчати частину курсу дистанційно, взаємодіючи з викладачем та іншими студентами на форумах, у блогах, електронною поштою; дистанційному навчанні з використанням кейс-технологій.

У процесі фахової підготовки майбутнього вчителя іноземних мов початкової ланки особливу увагу варто приділити роботі з технологією цифрового оповідання, що передбачає застосування навчальних мультимедійних презентацій, оскільки молодшому школяреві, 3 його наочно-образним мисленням зрозуміло лише те, що можна одночасно розглянути, почути або оцінити дію об'єкта. Мультимедійна 
презентація - це навчальний мінімультик, електронна звукова книжка 3 гарними картинками. В основі такої презентації лежить набір слайдів, на яких розміщуються текст і малюнки. Програма PowerPoint сама запрошує всю необхідну текстову і числову інформацію, а також надає безліч готових варіантів шаблонів і дизайну змісту, наприклад використання малюнків, часових інтервалів, фільмів, анімованих елементів і ефектів переходу [2].

До презентації можуть бути додані звукові ефекти і музика. Наразі, можна вибрати, як запускатиметься музика і який час вона повинна звучати. Діти можуть брати участь у створенні й озвучуванні слайдів, особливо у тому випадку, якщо вони разом $з$ учителем створювали власну історію, підбирали для неї персонажів, фонові картинки, що відображують місце подій і т. д.

Презентація несе в собі тип інформації, зрозумілий молодшим школярам, формує у них інтерес до навчання, пізнавальну активність. Завдяки презентаціям, навіть ті діти, які, зазвичай, не відрізняються високою активністю на уроках, активно висловлюють свою думку. Мультимедійні презентації дозволяють представити навчальний i розвивальний матеріал як систему яскравих опорних образів, наповнених вичерпною структурованою інформацією в алгоритмічному порядку. У цьому випадку задіюються різні канали сприйняття, що дозволяє закласти інформацію в пам'ять дітей не тільки в фактографічному, а й в асоціативному вигляді. Наразі значно зростає інтерес дітей до знань, підвищується рівень пізнавальних можливостей. Мультимедійні презентації - це зручний і ефектний спосіб представлення інформації за допомогою комп'ютерних програм. Він поєднує в собі динаміку, звук і зображення, тобто ті фактори, які найбільш довго утримують увагу дитини. За рахунок високої динаміки ефективно проходить засвоєння матеріалу, тренується пам'ять, розвиваються пізнавальна активність, уява i творчі здібності. Отже, полегшення процесу сприйняття i запам'ятовування інформації за допомогою яскравих образів - це основа будь-якої сучасної презентації. Попри це, презентація дає можливість вчителю самостійно скомпонувати навчальний матеріал, виходячи з особливостей конкретного класу, теми, предмета, що дозволяє побудувати урок так, щоб домогтися максимального навчального ефекту.

Створення умов для розвитку умінь створення навчальних матеріалів, на нашу думку, необхідно розробити комплекс завдань, спрямований на поетапне формування умінь використання мультимедійних комп'ютерних програмних засобів майбутніми вчителями іноземних мов початкової ланки у системі професійної підготовки. Завдання повинні передбачати можливість систематизації знань й умінь, отриманих у процесі бакалаврської підготовки, і бути спрямованими на набуття студентами знань щодо типів, видів мультимедійних комп'ютерних програмних засобів (1 етап), технологій ефективної роботи з мультимедійними комп'ютерними програмними засобами (2 етап), а також умінь використання мультимедійних комп'ютерних програмних засобів у власній професійно спрямованій діяльності (3 етап) .

Наведемо приклади професійно-орієнтованих вправ, спрямованих на поетапне формування умінь, як частини професійної підготовки студентів Інституту педагогіки Житомирського державного університету ім. I. Франка.

На першому етапі необхідно створити педагогічні умови, за яких студенти будуть здійснювати пошук і відбір інформації за попередньо встановленими критеріями. Наведемо приклад вправи:

Вправа, спрямована на формування вмінь знаходити, класифікувати та презентувати дані за допомогою мультимедійних комп'ютерних програмних засобів. 
Завдання: проведіть у групах міні-дослідження за темою "Учитель іноземної мови початкової ланки XXI століття" Підготуйте презентацію проекту "Професія вчителя іноземної мови початкової ланки: уміння XXI століття" для участі у студентській телеконференції за результатами дослідження. Виявіть у групах на основі огляду Інтернет-ресурсів:

- причини зміни ролі вчителя іноземної мови початкової ланки в суспільстві (група А);

- системи умінь сучасного вчителя іноземної мови початкової ланки (група Б);

- роль самоосвіти і саморозвитку на шляху до професійного педагогічного становлення сучасного вчителя іноземної мови початкової ланки (група В).

Хід виконання: студенти використовують результати пошуку, відбору та аналізу інформації для розв'язання завдання. Виконання завдання потребує узгодження нових відомостей з уже відомими.

Спосіб контролю: взаємоконтроль.

На другому етапі для формування вмінь використання мультимедійних комп'ютерних програмних засобів необхідно створити педагогічні умови, за яких студенти будуть здійснювати пошук і відбір інформації за попередньо встановленими критеріями. Дані будуть стосуватись можливостей використання мультимедійних комп'ютерних програмних засобів у професійній діяльності вчителя іноземної мови початкової ланки. Наведемо приклад вправи.

Вправа спрямована на формування умінь аналізу інформаційних джерел 3 точки зору їх дидактичних можливостей для майбутніх учителів іноземної мови початкової ланки.

Завдання: використовуючи запропоновані джерела, створіть i презентуйте можливості використання корисних ресурсів для вчителів у групах із заданої теми:

- методична і довідкова література, плани уроків, друкований роздатковий матеріал (група A);

- автентична аудіо- і відеоінформація (група Б);

- програми i ресурси для проведення телеконференцій, дистанційні курси навчання для вчителів (група В).

Хід виконання: студенти встановлюють критерії ефективного пошуку і відбору інформації. Виконання завдання передбачає узагальнення зібраних даних у таблицях і схемах, а також попередніх висновків щодо її корисності для розв'язання поставленого завдання.

Спосіб контролю: контроль з боку викладача.

Метою третього етапу $\epsilon$ створення власного продукту 3 використанням мультимедійних комп'ютерних програмних засобів майбутніми вчителями іноземних мов початкової ланки. Це надасть можливість майбутньому вчителю самостійно скомпонувати навчальний матеріал, щоб домогтися максимального навчального ефекту. Наведемо приклад вправи.

Вправа, спрямована на формування вмінь використання мультимедійних комп'ютерних програмних засобів для розв'язання дидактичних задач у процесі професійної спрямованої діяльності майбутнього вчителя, а також умінь критичного сприйняття й осмислення різнорідної педагогічної інформації, умінь формулювати на цій основі власні висновки й оціночні судження.

Завдання: проаналізуйте знайдені відомості із заданої теми. Визначте в групах іiі достовірність, переваги і недоліки, а також найбільш ефективні навчальні матеріали i ресурси та створіть на iї основі власний продукт з використанням мультимедійних 
комп'ютерних програмних засобів для використання на занятті з іноземної мови в школі.

Хід виконання: студенти осмислюють інформацію і її значущість для виконання поставленого завдання, зіставляють різні використання мультимедійних комп'ютерних програмних засобів для роботи з навчальним матеріалом. Результатом роботи можуть бути:

- презентації;

- цифрові оповідання тощо.

Спосіб контролю: взаємоконтроль.

\section{4. ВИСНОВКИ ТА ПЕРСПЕКТИВИ ПОДАЛЬШИХ ДОСЛІДЖЕНЬ}

Використання мультимедійних комп'ютерних програмних засобів у процесі фахової підготовки майбутнього фахівця з іноземних мов сприяє більш ефективному розв'язанню основних завдань, поглибленому вивченню змісту профільних предметів, оптимізації самоосвіти і саморозвитку майбутніх учителів на основі врахування їх особистісних особливостей, рівня підготовки, індивідуального способу сприйняття інформації і роботи з нею. Студенти опановують інтелектуальні знання, уміння аналізу, синтезу, зіставлення інформації, уміння робити об'єктивні висновки й ефективно використовувати результати аналізу інформації у власній професійно спрямованій діяльності. Для цього необхідна спеціальна організація навчального процесу, обгрунтування комплексу педагогічних умов, пошук i впровадження адекватних методів, способів, засобів навчання, які відповідають інноваційним освітнім тенденціям, рівню розвитку інформаційного суспільства. У подальшому пошуку ефективних шляхів розв'язання цієї проблеми ми вбачаємо перспективи наукового дослідження.

\section{СПИСОК ВИКОРИСТАНИХ ДЖЕРЕЛ}

1. Національна доповідь про розвиток освіти в Україні / Відпов. за випуск: Кремень В. Г. - Київ : Міністерство освіти і науки, 2001. - 39 с.

2. Ротмистров Н. Д. Мультимедиа в образовании // Информатика и образование. - 1994. - №4. - С. 89-96.

3. Самойленко Ю. Особливості використання мультимедійних комп'ютерних програмних засобів у процесі професійної підготовки майбутнього вчителя-філолога [Електронний ресурс]. - Режим доступу : http://www.kspu.kr.ua/ua/ntmd/konferentsiy/3-mizhnarodna-internet-konferentsiia2015/sektsiia-2/3549-osoblyvosti-vykorystannya-multymediynykh-komp-yuternykh-prohramnykhzasobiv-u-protsesi-profesiynoyi-pidhotovky-maybutnoho-vchytelya-filoloha.

4. Ротмистров Н. Д. Мультимедиа в образовании // Информатика и образование. - 1994. - №4. - С. 89-96.

Матеріал надійшов до редакиії 12.11.2016 p.

\section{МУЛЬТИМЕДИЙНЫЕ ПРОГРАММНЫЕ СРЕДСТВА В ПРОФЕССИОНАЛЬНОЙ ПОДГОТОВКЕ БУДУЩЕГО СПЕЦИАЛИСТА ПО ИНОСТРАННЫМ ЯЗЫКАМ В ДОШКОЛЬНОМ И НАЧАЛЬНОМ ОБРАЗОВАНИИ}

\section{Карпенко Евгения Николаевна}

кандидат педагогических наук, старший преподаватель

Житомирский государственный университет имени Ивана Франко, г. Житомир, Украина

karpenko26@i.ua 


\begin{abstract}
Аннотация. В статье рассматриваются возможные пути поэтапного использования мультимедийных программных средств в процессе профессиональной подготовки будущего специалиста по иностранным языкам начального звена, которые соответствуют инновационным образовательным тенденциям. Задачей учителя является построить учебный процесс таким образом, чтобы детям было интересно. Автор анализирует понятие мультимедийных программных средств и предлагает возможные пути поэтапного формирования умений использования мультимедийных программных средств будущими специалистами по иностранным языкам начального звена. Это позволит будущему учителю самостоятельно скомпоновать учебный материал, чтобы добиться максимального учебного эффекта.
\end{abstract}

Ключевые слова: мультимедийные компьютерные программные средства; будущий учитель иностранных языков начального звена; анимация; звуковые эффекты; графика; мультимедиа.

\title{
MULTIMEDIA COMPUTER SOFTWARE FOR THE PROFESSIONAL TRAINING OF PROSPECTIVE SPECIALISTS IN FOREIGN LANGUAGES FOR PRESCHOOL AND PRIMARY EDUCATION
}

\author{
Yevgeniia M. Karpenko \\ $\mathrm{PhD}$ (pedagogical sciences), seniour lecturer \\ Zhytomyr State Ivan Franko University, Zhytomyr, Ukraine \\ karpenko26@i.ua
}

\begin{abstract}
The article deals with possible ways of phasing the use of multimedia software in the process of training of the prospective specialists in foreign languages in preschool and primary education, which correspond to innovative educational trends. The task of the teacher is to build a learning process so that the children were interested. The author analyzes the concept of multimedia software and suggests possible ways of gradual formation of skills of using multimedia software for the prospective specialists in foreign languages in preschool and primary education. This will allow prospective teachers to use self-made educational material and maximize the teaching effect.
\end{abstract}

Keywords: multimedia computer software; prospective philology teacher; principal characteristics; possibilities; sound effects; animation; graphics; multimedia.

\section{REFERENCES (TRANSLATED AND TRANSLITERATED)}

1. The National Report on the Development of Education in Ukraine / Resp. for release: V.G. Kremen - Kyiv: Ministry of Education, 2001. - 39 p. (in Ukrainian)

2. Rotmistrov N.D. Multimedia // Informatika i obrazovanie. - 1994. - №4. - P. 89-96. (in Russian)

3. Samoilenko Y. The peculiarities of using multimedia computer software for the professional training of teacher-philologists [online]. http://www.kspu.kr.ua/ua/ntmd/konferentsiy/3-mizhnarodna-internet-konferentsiia-2015/sektsiia2/3549-osoblyvosti-vykorystannya-multymediynykh-komp-yuternykh-prohramnykh-zasobiv-uprotsesi-profesiynoyi-pidhotovky-maybutnoho-vchytelya-filoloha. (in Ukrainian)

4. Rotmistrov N.D. Multimedia in education // Informatics and education. - 1994. - №4.- P. 89-96. (in Russian)

Conflict of interest. The author has declared no conflict of interest.

\section{$(\mathrm{Cc})$ EY-NC-SA}

This work is licensed under Creative Commons Attribution-NonCommercial-ShareAlike 4.0 International License. 